\title{
An approach to the development of a national strategy for controlling invasive alien plant species: The case of Parthenium hysterophorus in South Africa
}

\begin{tabular}{|c|c|}
\hline $\begin{array}{l}\text { Authors: } \\
\text { Colette Terbla } \\
\text { Ingrid Nänni }{ }^{2} \\
\text { Haylee Kaplan } \\
\text { Lorraine W. St } \\
\text { Andrew J. McC } \\
\text { Jeremy Gooda } \\
\text { Brian W. van V }\end{array}$ & 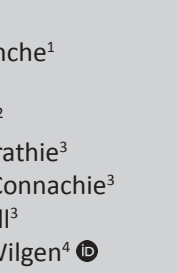 \\
\hline $\begin{array}{l}\text { Affiliations: } \\
{ }^{1} \text { Independent } \\
\text { Vryheid, South }\end{array}$ & $\begin{array}{l}\text { consultant, } \\
\text { Africa }\end{array}$ \\
\hline $\begin{array}{l}{ }^{2} \text { Invasive Speci } \\
\text { South African } \\
\text { Biodiversity In } \\
\text { Kirstenbosch R } \\
\text { Cape Town, So }\end{array}$ & $\begin{array}{l}\text { es Programme, } \\
\text { National } \\
\text { titute, } \\
\text { esearch Centre, } \\
\text { uth Africa }\end{array}$ \\
\hline $\begin{array}{l}{ }^{3} \text { Agricultural R } \\
\text { Council - Plan } \\
\text { Research Insti } \\
\text { South Africa }\end{array}$ & $\begin{array}{l}\text { esearch } \\
\text { Protection } \\
\text { ute, }\end{array}$ \\
\hline $\begin{array}{l}{ }^{4} \text { Centre for Inv } \\
\text { Department o } \\
\text { Zoology, Stelle } \\
\text { University, So }\end{array}$ & $\begin{array}{l}\text { asion Biology, } \\
\text { B Botany and } \\
\text { nbosch } \\
\text { th Africa }\end{array}$ \\
\hline $\begin{array}{l}\text { Correspondin } \\
\text { Brian W. van V } \\
\text { bvanwilgen@s }\end{array}$ & $\begin{array}{l}\text { author: } \\
\text { Vilgen, } \\
\text { un.ac.za }\end{array}$ \\
\hline $\begin{array}{l}\text { Dates: } \\
\text { Received: } 12 \mathrm{~J} \\
\text { Accepted: } 17 \\
\text { Published: } 24\end{array}$ & $\begin{array}{l}\text { an. } 2016 \\
\text { Apr. } 2016 \\
\text { June } 2016\end{array}$ \\
\hline $\begin{array}{l}\text { How to cite th } \\
\text { Terblanche, C. } \\
\text { Kaplan, H., Str } \\
\text { McConnachie, } \\
\text { Van Wilgen, B. } \\
\text { approach to th } \\
\text { of a national s } \\
\text { controlling inv } \\
\text { species: The ca } \\
\text { Parthenium hy } \\
\text { South Africa', } \\
\text { a2053. http:// } \\
\text { org/10.4102/a }\end{array}$ & $\begin{array}{l}\text { is article: } \\
\text { Nänni, I., } \\
\text { thie, L.W., } \\
\text { A.J., Goodall, J., } \\
\text { W., 2016, 'An } \\
\text { e development } \\
\text { rategy for } \\
\text { asive alien plant } \\
\text { se of } \\
\text { sterophorus in } \\
\text { othalia } 46(1) \text {, } \\
\text { dx.doi. } \\
\text { bc.v46i1.2053 }\end{array}$ \\
\hline Read online: & \\
\hline 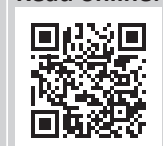 & $\begin{array}{l}\text { Scan this QR } \\
\text { code with your } \\
\text { smart phone or } \\
\text { mobile device } \\
\text { to read online. }\end{array}$ \\
\hline
\end{tabular}

Invasive alien species require co-ordinated strategic management if negative impacts are to be effectively avoided. Here we describe a strategy for the management of Parthenium hysterophorus L. (Asteraceae) in South Africa. P. hysterophorus is an annual herb native to tropical America, which has become invasive in over 30 countries. The strategy sets goals for (1) the prevention of spread to new areas; (2) local eradication of isolated populations; (3) containment in areas where eradication is not possible; and (4) actions to protect assets where containment is no longer an option. We developed both a national strategy to set policy and to monitor progress towards goals at a national level and an implementation plan to set goals and timeframes for their achievement at local levels. It is not clear, at this stage, whether or not the goals of the strategy are achievable because implementation will face many challenges arising from ecological features of the target plant, social and cultural practices that will influence management, inadequate levels of funding and multiple political considerations. Our strategy proposes regular assessment using high-level indicators, a practice that is widely recognised as essential but seldom implemented at a national scale. Because the outcomes are uncertain, it is vital that regular monitoring of outcomes should be instituted from the start, so that both appropriate adjustments can be made to the strategy and lessons for the implementation of similar strategies elsewhere can be derived.

\section{Introduction}

Growing numbers of invasive alien species are establishing and spreading in many parts of the world, and these invasions are often accompanied by substantial negative impacts on ecosystems, the economy and human health (Pimentel 2011). In response to these threats, many countries have ratified the Convention on Biodiversity, which requires signatory nations to 'prevent the introduction of, control or eradicate those alien species which threaten ecosystems, habitats or species'. While most of the signatory countries have developed high-level strategies for dealing with invasive alien species in general, very few have developed detailed strategies for individual priority species. In most cases, preventing or containing the impacts of a single invasive alien species that dominates over large areas will almost certainly be beyond the means of individual landowners. In such cases, effective control, if it is possible, has to be co-ordinated by governments, often at a national scale. There is thus a distinct need for co-ordinated, strategic approaches that will increase the chances of achieving sustainable and effective control.

In Australia, a relatively small number of invasive alien plant species (20 in the year 2000 rising to 32 in 2014) has been designated as Weeds of National Significance (WONS, see Thorp and Lynch 2000). Grice, Clarkson \& Calvert (2011) proposed the use of a geographically differentiated strategy for the management of the invasive wetland grass Hymenachne amplexicaulis (Rudge) Nees (Poaceae), one of Australia's WONS. Their approach recognises that different objectives and methods would be appropriate for different parts of a species' introduced range, or areas that it might yet invade. Based on the suitability of areas for invasion, and on the absence, presence or abundance of the species, they formulated four appropriate responses: Prevention of invasion for areas where the species was not yet present (given low priority in unsuitable habitats, and high priority elsewhere); local eradication where it was deemed feasible; containment where eradication was no longer possible, but where control was still feasible; and asset protection where containment was not feasible any more. On the basis of this classification, Grice et al. (2011) divided Australia into 21 management zones, each of which was assigned one of the four objectives, and they suggested that this approach could be usefully applied to other invasive species to more effectively

Copyright: (C 2016. The Authors. Licensee: AOSIS. This work is licensed under the Creative Commons Attribution License. 
address their broad-scale management. The effectiveness of this approach is yet to be assessed, and its widespread and effective implementation is likely to face a range of challenges, especially if the approach is to be adopted in developing countries where resources and management capacity are limited, and where perceptions of the importance of the problem differ.

Notwithstanding the challenges facing developing countries, South Africa has recently (2014) promulgated regulations (under the National Environmental Management: Biodiversity Act, Act 10 of 2004, hereafter NEM:BA) that provide for the establishment of national-level invasive species management programmes for priority invasive alien species. The regulations further require that an 'invasive species control and eradication strategy' should be drawn up to guide each management programme. A list of priority species has not yet been finalised, and this may take some time, but in view of the urgent need to develop guidelines and test approaches for such strategies, it was decided to develop a strategy for the invasive alien weed Parthenium hysterophorus L. (Asteraceae), known locally as famine weed (Macdonald 2014).

In this paper, we provide a brief description of the development of a strategy and implementation plan for the management of P. hysterophorus in South Africa, and we discuss the challenges for the expansion of the approach to other species and to other developing countries.

\section{Parthenium hysterophorus in South Africa}

Parthenium hysterophorus is an annual herb native to tropical America, and it has become invasive in at least 34 countries in Africa, Asia, Australia and the Middle East (Adkins \& Shabbir 2014). The species was first recorded in South Africa in 1880 (Wood 1897) but remained an uncommon weed restricted to cultivated and disturbed areas for almost 100 years (Hilliard 1977). The presence and abundance of invasive alien plant species in South Africa is recorded within quarterdegree grid cells (cells of approximately $25 \times 25 \mathrm{~km}$ ) in the Southern African Plant Invaders Atlas (Henderson 2007). In 1980, P. hysterophorus was found in only three cells, but this had reached 15 cells by 2000, and then rose rapidly to 62 cells in 2007 and to 76 cells in 2014 (Figure 1). Parthenium hysterophorus causes severe allergic reactions (dermatitis, hay fever and asthma) in a large proportion of people who come into contact with it, as well as in livestock and wildlife (Towers \& Mitchell 1983; Patel 2011). The potential for the species to have serious consequences for the agricultural economy, human health and biodiversity (Wise et al. 2007), coupled with its recent rapid expansion, have contributed to its preliminary selection as a priority species.

Parthenium hysterophorus currently occurs in four South African provinces in the northeast of the country, as well as in neighbouring Swaziland and Mozambique (Figure 1). Climatic suitability modelling (McConnachie et al. 2011) indicates that it could potentially spread to a much larger area (Figure 2). The biology of P. hysterophorus is characterised by rapid growth and flowering, and copious seed production. While the species is not aggressively competitive in healthy vegetation, it thrives in disturbed areas and is dispersed by a wide range of vectors, including water, animals, vehicles, tools and machinery. The species readily invades disturbed or overgrazed areas, and seed banks can persist in the soil for up to six years (Navie et al. 1998). Controlling P. hysterophorus in South Africa will not be an easy task, given the country's wide network of tarred and dirt roads and tracks, high population density with low socio-economic status in many areas, communal grazing and poor rangeland management practices that together have created conditions that promote invasion. The most effective available management options include minimising spread, eliminating isolated outbreaks, maintaining rangelands in good condition ( $P$. hysterophorus more readily invades degraded areas) and the use of introduced biological control agents. Minimising the spread of this weed will require regular checking and cleaning of vehicles and machinery moving from infested to uninfested areas. Isolated outbreaks should be treated promptly by applying herbicides and identifying new outbreaks will require awareness and an ability to recognise the species.

In late 2003, South Africa initiated research to investigate the potential for using biological control to combat P. hysterophorus (Strathie, McConnachie \& Retief 2011), based on the successful management of this species in Australia using nine introduced natural enemies there. In Australia, the extent and density of $P$. hysterophorus has been substantially reduced as a result of concerted biological control efforts between the 1970s and the present (Dhileepan \& McFadyen 2012). In South Africa, three species of biological control insects and one rust fungus have been released following assessment of their suitability for introduction. Another rust fungus that was probably introduced simultaneously with $P$. hysterophorus is also present, and other agents are under investigation. Establishment of these agents, although currently limited and variable, is evident. Active attempts to control the species using herbicides also began in 2011, as part of an employment and poverty relief programme.

\section{Developing a national strategy}

South Africa's NEM:BA legislation requires that the Minister of Environmental Affairs (who is responsible for the implementation of this Act) 'must ensure the coordination and implementation of programmes for the prevention, control or eradication of invasive species [section 75(4)]. The regulations in terms of NEM:BA, approved in October 2014, require [section 2(3)] compliance by landowners with such an Invasive Species Management Programme, where such a programme exists. During the course of 2014, workshops involving a range of stakeholders were convened to gather inputs for the development of a National Invasive Species Management Programme for $P$. hysterophorus. This resulted in the drafting of a 'control and eradication strategy', as envisaged in the NEM:BA 


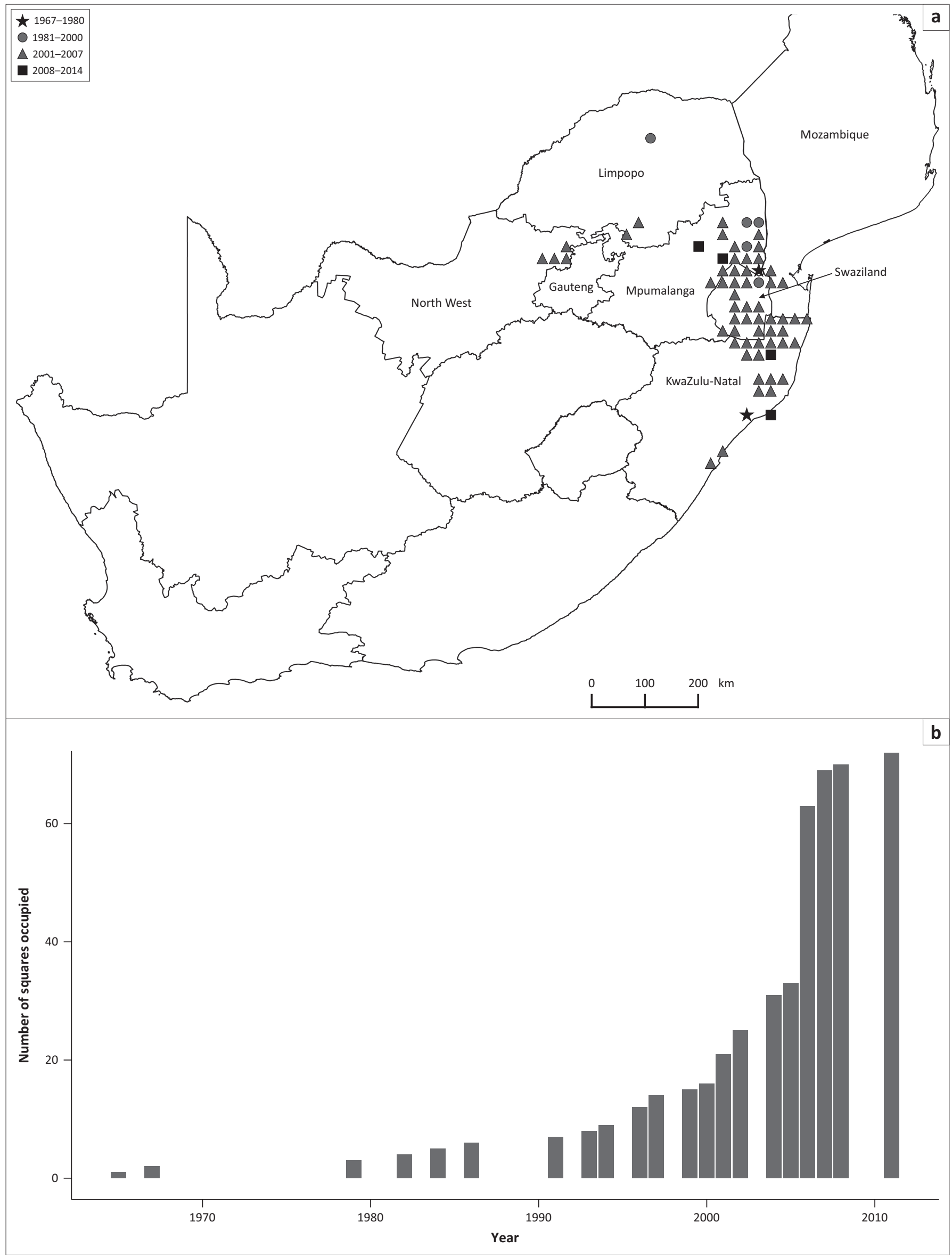

FIGURE 1: (a) Current distribution of Parthenium hysterophorus in South Africa and Swaziland; (b) Historical occurrence showing the number of quarter-degree cells in which the species was present over time. Data are from the Southern African Plant Invaders Atlas (Henderson 2007). 


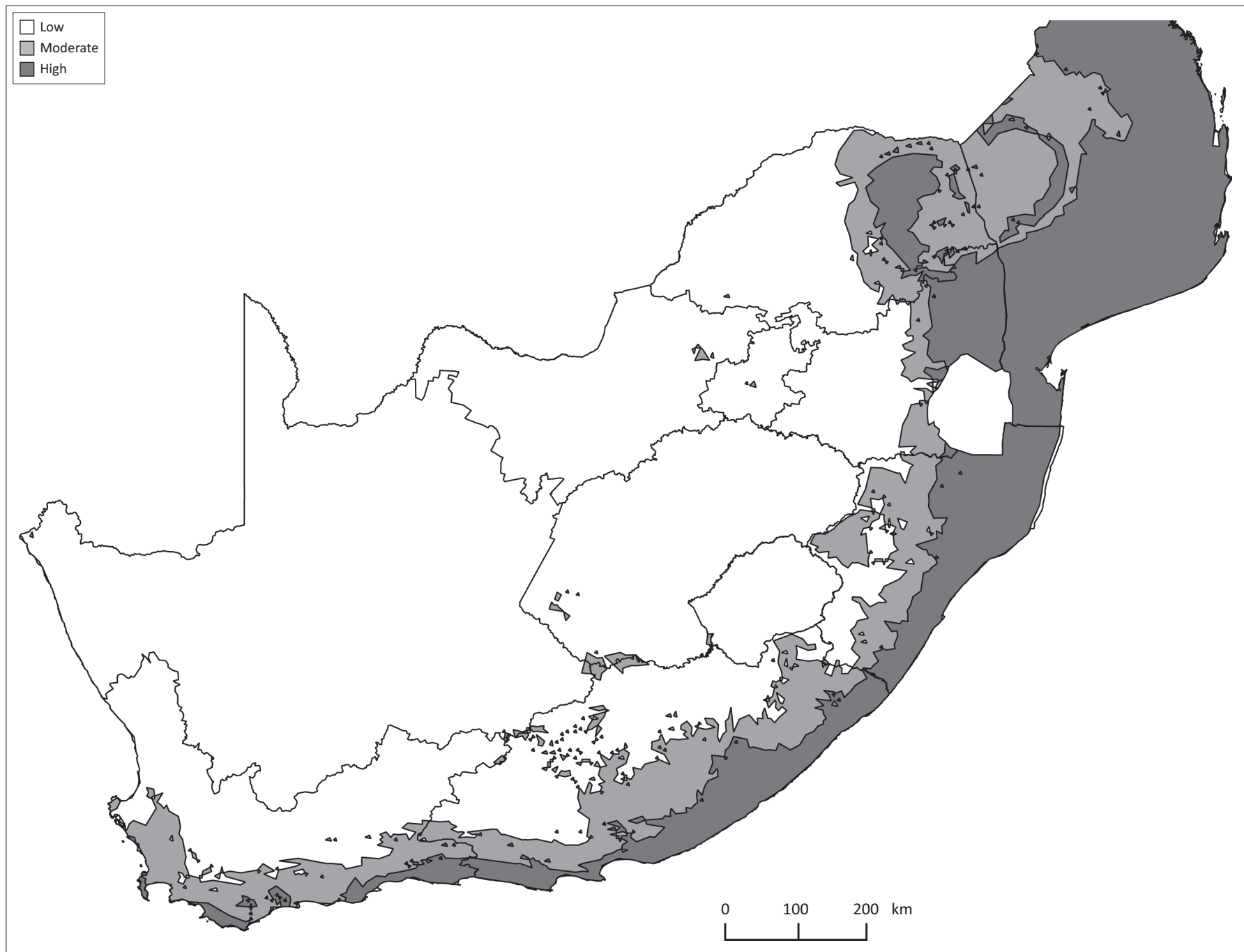

FIGURE 2: The potential distribution of Parthenium hysterophorus in South Africa and southern Mozambique, based on three classes of climatic suitability (adapted from McConnachie et al. 2011).

regulations. Inputs by three national and two international experts further improved the document. The strategy described in this paper is based on the draft control and eradication strategy, and provides high-level guidelines for the management of P. hysterophorus in South Africa. These guidelines will be given effect in a National Implementation Plan. Grice et al.'s (2011) framework for geographic differentiation was adopted to guide the formulation of the South African national strategy and the associated implementation plan for P. hysterophorus. While Grice et al. (2011) used the term 'strategic plan' to describe their framework, we consciously developed two documents, a NationalStrategy (Terblanche2014a) and an Implementation Plan (Terblanche 2014b). The National Strategy reviewed the situation in South Africa, provided broad strategic goals, allocated land to management zones following Grice et al.'s (2011) framework and proposed high-level performance indicators. The implementation plan provided for the establishment of a national programme overseen by a national co-ordinator and guided by a multi-departmental steering committee, listed appropriate management actions to be taken in each zone and assigned responsibilities and timeframes for the achievement of targets based on available funding.

\section{Outcomes of the process}

\section{Key features of the national strategy}

The national strategy identified five broad goals, the first of which was to establish a national invasive alien species control programme (as envisaged in NEM:BA) with adequate funding and management capacity to achieve the remaining goals. It was further recognised that a successful national programme would require cross-sectoral coordination and collaboration between different spheres of government and stakeholders within South Africa, and within countries bordering South Africa. The remaining four goals align with those proposed by Grice et al. (2011), namely to prevent the establishment of $P$. hysterophorus in regions where it is not already present; to detect and locally eradicate new infestations wherever possible; to contain further spread of existing infestations or reduce their extent where possible; and to reduce the impacts on selected assets where containment is no longer possible.

It was explicitly recognised that the achievement of these goals would require interventions that would (a) increase awareness of the problem among stakeholders, enabling them to recognise the species in areas where it has not 
occurred as yet, to appreciate the species' potential impacts and to understand the available management options; (b) ensure that biological control is used to the fullest possible extent to reduce the impacts of $P$. hysterophorus and to supplement other control methods; and (c) encourage the use of sound rangeland management practices that would reduce the risks of further invasion in degraded areas.

Local government in South Africa is overseen by eight metropolitan municipalities and 226 local municipalities, which together cover the whole country. We used municipal boundaries to delineate management zones, as development planning at a local level takes place within municipalities in South Africa. We used the decision tree by Grice et al. (2011) to assign each municipality to one of the five zones: Low-priority prevention areas where the species is not yet present and where habitat is unsuitable for invasion by $P$. hysterophorus; high-priority prevention areas where the species is not yet present but where suitable habitat exists (applicable if $>1 \%$ of the municipality has a moderate to high probability for invasion based on climatic suitability,
Figure 2); local eradication areas where P. hysterophorus exists in localised, low-density populations and where local eradication is deemed feasible; containment areas invaded by $P$. hysterophorus where eradication would not be possible, but where containment is still feasible; and asset protection areas with widespread, dense invasions where containment is not feasible. As detailed distribution data for P. hysterophorus were not available, municipalities were assigned to zones during workshops with stakeholders, based on limited data and individual local knowledge (Figure 3).

\section{Implementation and assessment of the national strategy}

A range of high-level interventions associated with each of the five broad goals of the strategy were identified, along with performance indicators that could be used to assess progress towards the goals (Table 1). It was decided, at this stage, not to assign targets for the indicators in the strategy, but rather to address management targets in the implementation plans, for two reasons. Firstly, targets would need to be assessed in terms of baseline values that reflect

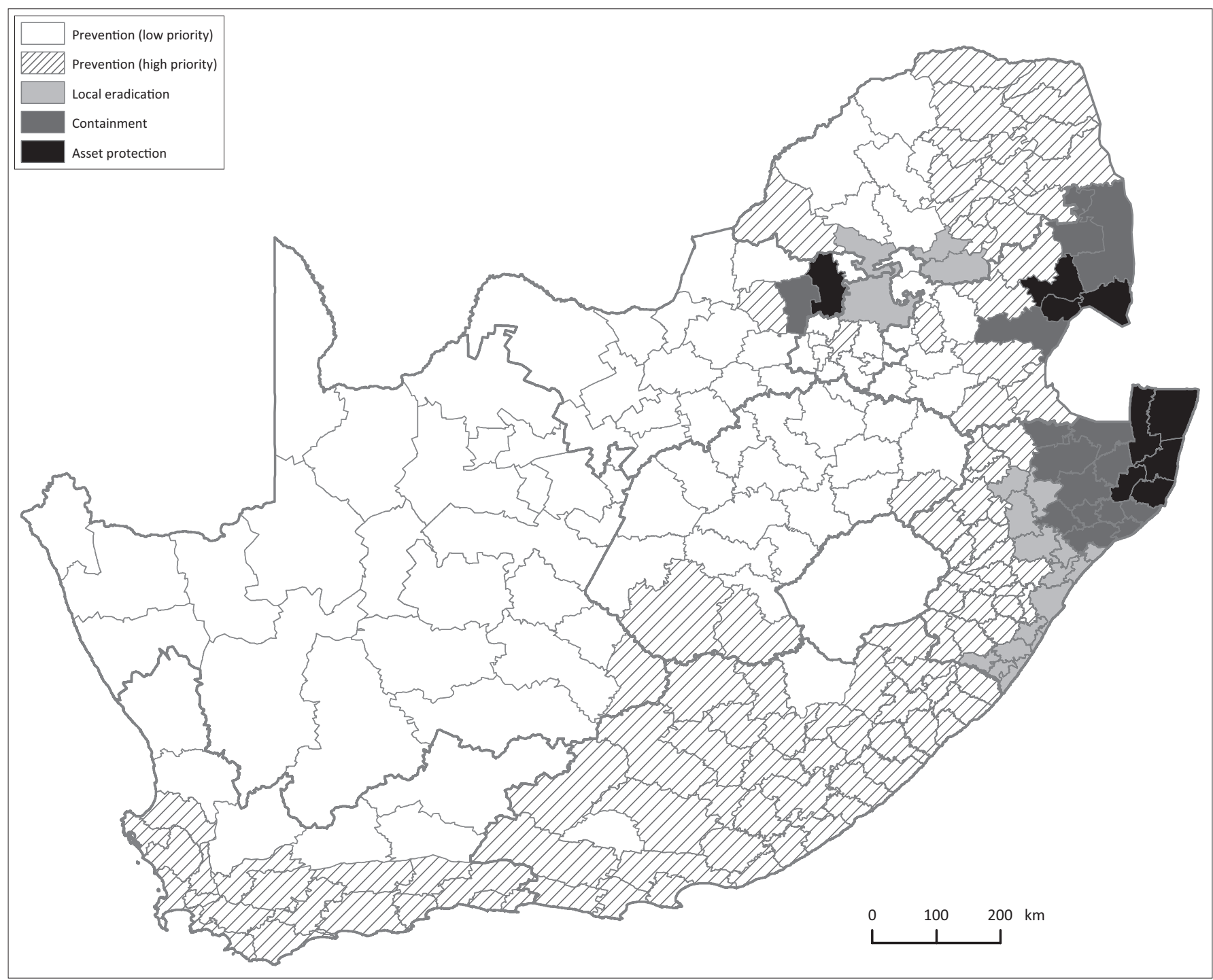

FIGURE 3: Allocation of management zones for the control of Parthenium hysterophorus, based on the degree to which they occur in municipalities across South Africa. Current and future potential occurrence in municipalities was based on data from the Southern African Plant Invaders Atlas (Figure 1A), on climatic suitability (Figure 2), and on expert and local knowledge, according to rules described in Table 2. Management zones are defined in Table 3. 
current reality, and accurate data on baseline values are currently not available (e.g. accurate estimates of the extent of invasion are not available, and there is much uncertainty regarding the funds available to support the different interventions). Secondly, a meaningful and valid commitment to targets can only be made by politicians mandated to administer public funds, and this would require a process of engagement and negotiation that has not yet taken place. The intent, therefore, is to use the indicators as a starting point for establishing baseline values, with the view to political engagement that would lead to agreed targets at a later stage.

The establishment of a national invasive alien species control programme for $P$. hysterophorus will require formal approval in terms of NEM:BA, after which a national co-ordinator can be appointed and an inter-departmental steering committee established. The national invasive alien species control programme would be managed from within the national Department of Environmental Affairs (DEA), and the national co-ordinator would be an employee of that department, and would act as chair of the steering committee. The management of invasive alien species is of relevance to, or is influenced by, a number of government departments, notably those responsible for the environment, agriculture, forestry, transport and human health (at national, provincial and local levels), and a steering committee is intended to bring a co-ordinated approach to management that is viewed as an essential ingredient for success. The committee needs to be representative but small enough to be effective. The committee would be responsible for overall co-ordination, identifying sources of funding and monitoring progress in terms of agreed indicators (Table 1).
An important component of the strategy will be to raise awareness of the problem among key stakeholders for two reasons. Firstly, in areas where the species is not yet present, people need to be made aware that it could establish there, and they need to be able to recognise the species. The strategy suggests that this awareness should be created primarily among organisations with existing invasive alien plant clearing operations and agricultural extensions officers, who could report sightings through an online reporting system (www.ispotnature.org/communities/southern-africa). Secondly, where the species is present, people need to be aware of the dangers that it poses, the ways in which spread and impact can be reduced and the methods available for control. To achieve this, educational material needs to be produced and key stakeholders need to be engaged. The intention is to develop a manual that outlines best management practices regarding the containment and control of $P$. hysterophorus. Most importantly, awareness of the need to limit spread (by limiting the movement of vehicles, livestock and fodder between invaded and uninvaded areas) and to sanitise vehicles and machinery where movement is unavoidable needs to be fostered (see Brunel et al. 2014). This final aspect may be difficult to implement broadly in developing countries like South Africa, except in selected areas (such as the entrance gates to protected areas, where heavy traffic creates a high risk of seed introduction).

Biological control is seen as an indispensable aspect of the strategy. Of the 34 countries where P. hysterophorus has invaded, only Australia has managed to achieve a reasonable

TABLE 1: Goals of the national strategy for managing Parthenium hysterophorus, with associated high-level management interventions and proposed indicators.

\section{Strategic goal}

Establish a national invasive alien species contro programme

\begin{tabular}{|c|c|}
\hline \multirow[t]{3}{*}{ programme } & Quantify and source the necessary funding \\
\hline & Establish an inter-departmental steering committee \\
\hline & Establish a forum to co-ordinate research \\
\hline $\begin{array}{l}\text { Prevent establishment in } \\
\text { unoccupied areas }\end{array}$ & $\begin{array}{l}\text { Identify major pathways of spread and manage to reduce risks of } \\
\text { movement }\end{array}$ \\
\hline \multirow[t]{5}{*}{$\begin{array}{l}\text { Detect and locally eradicate } \\
\text { new infestations }\end{array}$} & $\begin{array}{l}\text { Undertake training to raise awareness in targeted groups } \\
\text { (e.g. agricultural extension officers) }\end{array}$ \\
\hline & Use remote sensing to detect new infestations \\
\hline & Undertake rapid assessments when sightings are reported \\
\hline & Commit to a local eradication campaign \\
\hline & Confirm local eradication \\
\hline \multirow[t]{5}{*}{$\begin{array}{l}\text { Contain further spread of } \\
\text { existing infestations }\end{array}$} & $\begin{array}{l}\text { Map invasions to provide a basis for developing management } \\
\text { plans and assessing the effectiveness of management }\end{array}$ \\
\hline & $\begin{array}{l}\text { Raise awareness among target groups } \\
\text { (e.g. land users in infested areas) }\end{array}$ \\
\hline & Develop and implement management plans \\
\hline & Engage with stakeholders to improve rangeland management practices \\
\hline & Expand the biological control programme \\
\hline
\end{tabular}

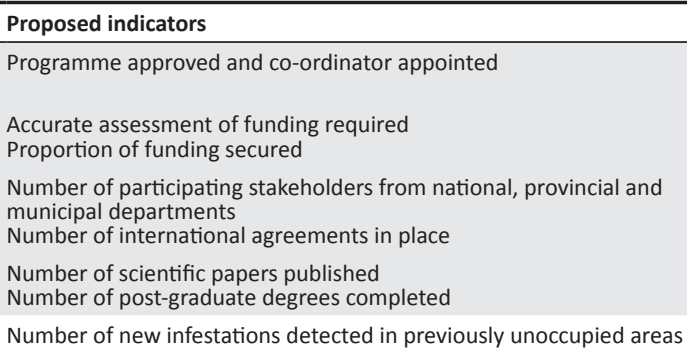

Number of training sessions in high-risk areas

Number of high-risk areas surveyed

Number of reported sightings and time taken to carry out assessments Number of campaigns approved on the basis of assessments and adequate management plans

Number of successful approved local eradication campaigns

Area covered by populations of $P$. hysterophorus

Number of awareness pamphlets distributed

Number of presentations made

Number of press articles published

Number of municipalities in containment zones covered by provincial management plans

Proportion of rangelands in healthy condition

Funding available for biological control research

Number of new biological control agents approved and released Number of mass-rearing facilities established

Increases in the effectiveness of biological control

Number of municipalities in asset protection zones with accurate maps

Number of municipalities in asset protection zones covered by provincial management plans 
degree of control, and this is largely because of the use of biological control. The combination of a suite of natural enemies was required to achieve significant reductions in the abundance and impact of $P$. hysterophorus under different circumstances and seasons in Australia (Dhileepan \& McFadyen 2012). In 2003, South Africa became the first African country, and only the third country worldwide, to implement a biological control programme against P. hysterophorus (Strathie et al. 2011). This research is funded by the DEA and is carried out by the Plant Protection Research Institute within the Agricultural Research Council. The research will be continued and expanded, and the distribution of approved biological control agents will be strengthened through the use of mass-rearing facilities, sited in asset protection zones with dense infestations.

The potential for using remote sensing to detect and map the occurrence and distribution of $P$. hysterophorus has been improved by recent developments in remote sensing technology. Satellite Pour l'Observation de la Terre (SPOT) 6 can now be used to generate maps of the distribution of $P$. hysterophorus at a spatial resolution of $6 \mathrm{~m}$. The intent is to produce a tool for semi-automated annual monitoring of the $40 \%$ area of South Africa identified as suitable for invasion by P. hysterophorus (Figure 3), at the appropriate spatial scale and classification accuracy, so that new infestations can be detected early and progress of management interventions can be monitored.

In areas where $P$. hysterophorus has reached such high densities that containment will no longer be possible, the strategy will be to focus on the protection of assets. In this case, given the potential impacts on human health, clearing operations will focus on areas where large numbers of people gather, including clinics, bus stops and schools. Road verges will be regularly cleared to reduce the risks of further spread by means of passing vehicles, and it may also be desirable to attempt to clear infestations from protected areas.

The need for research is recognised in the strategy, and it is proposed to establish a research forum, under the auspices of the programme steering committee, to co-ordinate and review research and to foster information and technology transfer. Priority research topics that have been identified at this stage include the development of biological control solutions and remote sensing applications, the management and reduction of predicted impacts on human health and cultural issues affecting rangeland management.

Finally, engagement with international stakeholders is seen as vital. Gaining control of the existing problem in neighbouring Swaziland and Mozambique will be crucial for the achievement of long-term goals in South Africa, while prevention of spread to other neighbouring countries will require international efforts to prevent spread to new areas. With this in mind, the national steering committee will be tasked with fostering collaborative engagement with neighbouring countries.

\section{Key features and assessment of the implementation plan}

The implementation plan has been designed to guide actions aimed at achieving the strategic goals outlined above. It sets targets that need to be achieved within a defined timeframe and serves as a framework for the allocation of funds to various projects within the national programme (Table 2). In the case of $P$. hysterophorus, it was decided to recommend the appointment of two regional managers responsible for implementation in the coastal province (KwaZulu-Natal)

TABLE 2: Goals, actions and targets associated with the implementation of regional management plans for the control of Parthenium hysterophorus in different management zones.

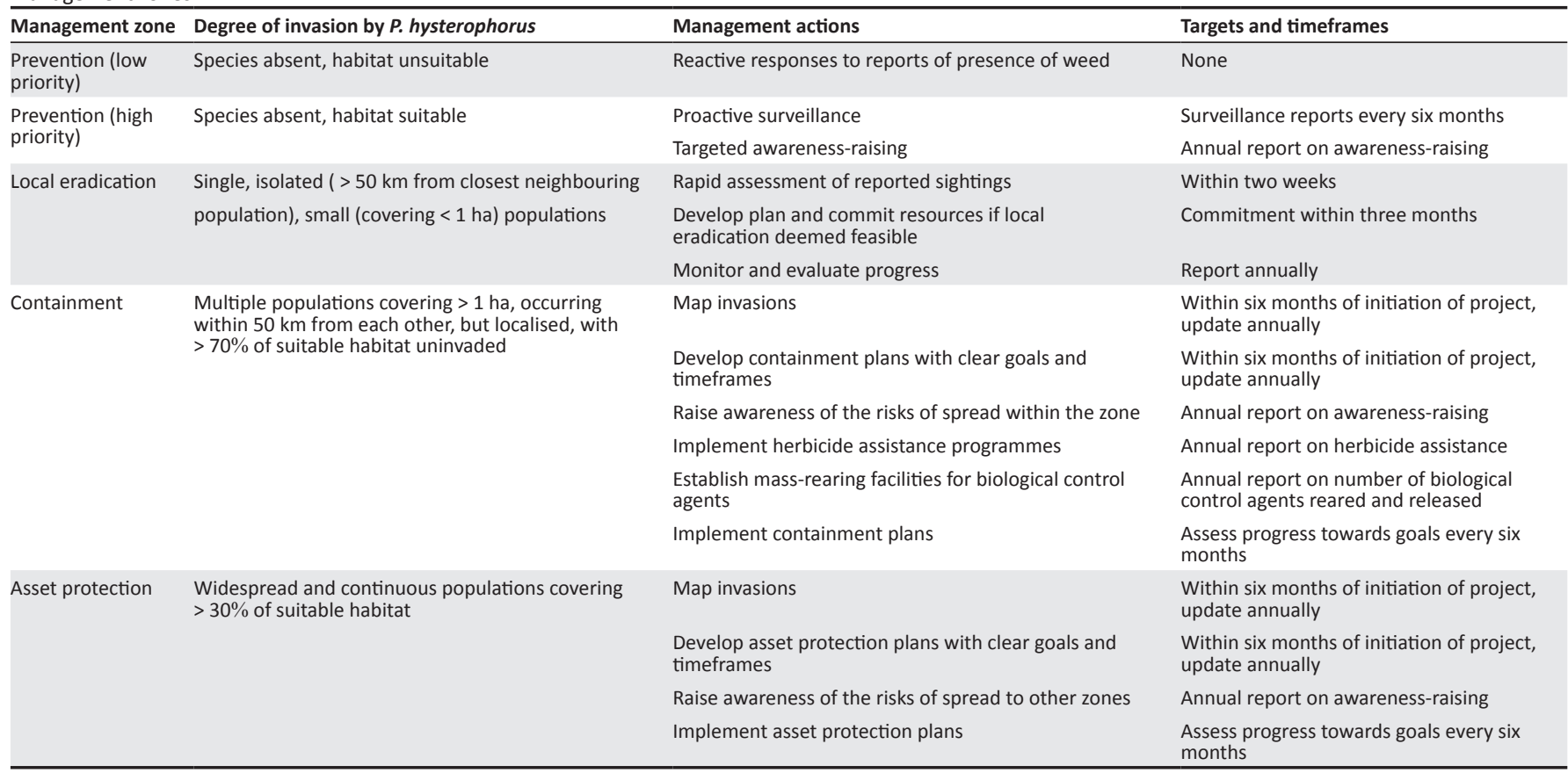

Note: Thresholds for the degree of invasion are first approximations and can be altered if needed. 
and inland provinces, respectively. They will report to the national co-ordinator and will be responsible for all activities within their regions. In addition, a database manager and a communications manager will be appointed in each region to oversee GIS mapping and other record-keeping and for awareness-raising, respectively. Within each of these regions, local municipalities will be assigned to one of the five zones and managed accordingly (Table 2). The zones assigned to local municipalities will be reviewed annually, and their status can change depending on the circumstances. For example, if it proves impossible to eradicate a localised population, the municipality will be rezoned from a 'local eradication' to a 'containment' zone; likewise, in the case where containment goals are not achieved, a municipality can be rezoned from a 'containment' to an 'asset protection' zone. In an ideal world, 'local eradication' zones could be assigned to 'high-priority prevention' zones if local eradication is achieved.

Regional management plans (one each for the coastal and inland regions) will in effect be compiled 'bottom-up' from targets set and resources assigned to individual municipal areas. Landowners (on private land) and traditional authorities (on communal land) will be encouraged to adhere to best practice guidelines, which will be drawn up and distributed as part of the implementation of the strategy. State subsidies will be made available for the purchase and use of herbicides to control P. hysterophorus. On state-owned land (e.g. in protected areas), control will be carried out in terms of the protected area's management plan, or catered for by other plans (e.g. along road reserves and at government schools and clinics), and supported by labour funded through the 'Working for Water' poverty relief programme (see van Wilgen, Le Maitre \& Cowling 1998).

Given that funding will almost certainly be a limiting factor, it will be necessary to prioritise interventions. Municipalities with high human population densities, well-managed rangelands and important protected areas, and municipalities that could act as source populations for further spread will be given higher priority over other areas. Sufficient funding should be allocated to priority municipalities, recognising that the alternative (dilution of funding to cover all municipalities) would lead to control efforts falling below a threshold at which the management at all of the municipalities would become ineffective. Assigning priorities and ensuring the effective use of funds will be one of the most challenging aspects of implementation.

Management plans for individual municipalities should meet minimum criteria. These include the formulation of realistic goals that can be met within specified timeframes; the effective integration of mechanical, chemical, biological and other control methods (van Wilgen et al. 2011); and the co-ordination of the activities of all stakeholders in the municipal area. Bi-annual progress reports should explicitly address progress towards these goals, and where progress falls short of planned targets, action should be taken to correct the shortfalls. If targets are demonstrably not achievable, the goals of the plans will need to be re-assessed. An adaptive approach to management, which requires that plans should be as flexible as possible to accommodate unforeseen setbacks or unplanned events (e.g. droughts, floods or fires), will need to be adopted.

\section{Discussion Challenges to implementation}

Growing infestations of $P$. hysterophorus will almost undoubtedly have serious consequences for rural economies and the health of people in the invaded areas of South Africa and neighbouring countries. For example, Wise et al. (2007) found that if $P$. hysterophorus were allowed to spread without control, returns to small-scale farmers could decline between $26 \%$ and $41 \%$. Ways of avoiding or mitigating these impacts should therefore be sought. Wise et al. (2007) further found that the effectiveness of control needed to be greater than $50 \%$ for the investment to deliver a positive benefit:cost ratio. This supports the adoption of a strategic approach that seeks to guide the implementation of such efforts and to increase the effectiveness of control.

The strategy described here is yet to be implemented, and those tasked with doing so will face several challenges. A number of diverse factors contribute to the creation of these challenges, and they include ecological features of the target plant as well as the habitats that it invades, social and cultural practices that will influence management, inadequate levels of funding and multiple political considerations (Table 3). It is therefore not clear, at this stage, whether or not the goals of the strategy will be achieved, or even if they are achievable. Despite these uncertainties, large sums of money have been spent (and continue to be spent) on the control of $P$. hysterophorus, and the effectiveness of control needs to be increased above a threshold at which the control becomes economically viable. A strategic approach to control, and a close monitoring of its implementation, will therefore be essential if the likely consequences of failure to control P. hysterophorus are to be avoided.

Many weed control programmes fail to set targets or to assess their progress towards targets, for a range of reasons (Denslow \& D'Antonio 2005; Reid et al. 2009). These include the fact that few managers have the long-term funding, expertise or access to guidance that would underpin assessments, nor are they often in a position to collect the high-quality, quantitative data necessary to conduct assessments. In cases where assessments are made, there is no impetus to publish them, making the few results that do exist difficult to locate. It is nonetheless well recognised that evaluation during and after alien species control programmes is vital for effective management, and that schemes for regular evaluation should be planned well before any control is initiated (Blossey 1999).

The above shortcomings need to be recognised and addressed by those who will be tasked with implementing this strategy. In South Africa, as elsewhere, scant attention has been paid to 
TABLE 3: Problems and contributing factors that will lead to challenges in the implementation of a national strategy for the control of Parthenium hysterophorus in South Africa.

\begin{tabular}{|c|c|c|}
\hline Problem & Contributing factors & Challenge \\
\hline Rapid spread of the target weed & $\begin{array}{l}\text { An abundance of vectors combined with a dense network of } \\
\text { roads and a high human population }\end{array}$ & $\begin{array}{l}\text { Accurate monitoring of spread to assess } \\
\text { effectiveness of management interventions }\end{array}$ \\
\hline Jurisdiction over management limited to South Africa & Continuous distribution of the weed across international borders & $\begin{array}{l}\text { Fostering international collaboration in control } \\
\text { efforts }\end{array}$ \\
\hline $\begin{array}{l}\text { The weed readily invades overgrazed rangelands and } \\
\text { other degraded areas }\end{array}$ & $\begin{array}{l}\text { Cultural practices on communal land that place a high value on } \\
\text { cattle, often leading to overgrazing and rangeland degradation }\end{array}$ & $\begin{array}{l}\text { Reconciling differences between cultural values } \\
\text { and rangeland management to a level that will } \\
\text { reverse degradation }\end{array}$ \\
\hline Chemical and mechanical control is not always effective & $\begin{array}{l}\text { Control methods are often not applied correctly, and there is a } \\
\text { lack of adequate planning }\end{array}$ & $\begin{array}{l}\text { Ensuring adequate planning and the consistent use } \\
\text { of best management practices }\end{array}$ \\
\hline Multiple management goals & $\begin{array}{l}\text { Projects are supported by poverty relief funds, which require a } \\
\text { focus on employment, necessitating trade-offs between job } \\
\text { creation and ecological goals }\end{array}$ & $\begin{array}{l}\text { Maintaining a focus on priority areas for weed } \\
\text { control, in the face of pressure to work in } \\
\text { alternative areas that are a priority for poverty } \\
\text { relief }\end{array}$ \\
\hline Funding is likely to be inadequate & Competing demands for scarce funding & $\begin{array}{l}\text { Making effective use of limited funds through } \\
\text { increasing efficiencies and focussing on agreed } \\
\text { priorities }\end{array}$ \\
\hline Low levels of awareness regarding the weed & $\begin{array}{l}\text { Inability to recognise the weed until it becomes well-established } \\
\text { and ignorance of effective methods for control }\end{array}$ & $\begin{array}{l}\text { Raising awareness to adequate levels in target } \\
\text { groups }\end{array}$ \\
\hline $\begin{array}{l}\text { Responsibilities under legislation are poorly understood } \\
\text { and not enforced }\end{array}$ & $\begin{array}{l}\text { Complexity of the legislation and a lack of capacity to ensure } \\
\text { compliance }\end{array}$ & $\begin{array}{l}\text { Encouraging compliance in a way that will benefit } \\
\text { landowners and contribute to widespread control }\end{array}$ \\
\hline $\begin{array}{l}\text { Insufficient collaboration between multiple arms of } \\
\text { government, leading to poor integration of control efforts }\end{array}$ & $\begin{array}{l}\text { Priorities differ between departments, leading to inadequate } \\
\text { attention being paid to this strategy }\end{array}$ & $\begin{array}{l}\text { Establishing and maintaining an effective } \\
\text { co-ordinating committee }\end{array}$ \\
\hline Lack of capacity at municipal level & $\begin{array}{l}\text { Insufficient resources and lack of expertise and capacity housed } \\
\text { within municipal structures }\end{array}$ & $\begin{array}{l}\text { Increasing knowledge and capacity at all levels } \\
\text { within zones }\end{array}$ \\
\hline
\end{tabular}

monitoring and evaluating the outcomes of management, for a range of reasons (van Wilgen et al. 2012; van Wilgen \& Wannenburgh 2016). The risk exists, therefore, that it may not be possible to assess the effect of implementing this strategy unless monitoring and evaluation of indicators is taken seriously from the start. As a result of the challenges summarised in Table 3, the implementation of elements of this strategy may fail to deliver the desired outcomes. It would also be important to recognise this at the outset and to plan for alternative approaches to be adopted if and when it becomes apparent that the desired outcomes are not being achieved (Table 4). For example, although we have included 'local eradication' zones proposed by Grice et al. (2011) in our strategy, other research has suggested that not all approaches will be suitable for all weed species, and specifically that the eradication of outliers should not be considered where weeds have short juvenile periods and long-lived seeds (Panetta \& Cacho 2014). It is therefore entirely plausible that this aspect of management will fail for this particular weed, given its ability to rapidly disperse and establish in new areas, its annual life cycle and the fact that viable seeds remain in the soil for several years.

Outcomes for other important indicators are also uncertain and could vary from positive to negative (Table 4). These include a failure to develop adequate management plans (necessitating steps to expedite or support planning) or to achieve the desired degree of impact using biological control (impact could vary from complete to negligible control, with far-reaching implications for elements of the strategy). Ultimately, the success of the strategy will be gauged by the degree to which the weed populations are contained or reduced. Assessing this will not be easy, as national-scale control operations are not laid out as experiments with adequate treatments and controls (Kettenring \& Adams 2011), but the use of evidence-based approaches for assessing the effectiveness of environmental programmes holds promise for overcoming these challenges (Ferraro \& Hanauer 2014).
Implementation of the strategy would have to proceed for several years before it could be reasonably expected that outcomes could be adequately assessed. It would nonetheless be important to institute annual assessments from the start, recognising that outcomes will be uncertain and that there has to be a willingness to adapt depending on the trends detected. In this way, it will be easier both to be able to make appropriate adjustments to the strategy and to derive lessons for the use of similar strategic approaches elsewhere.

\section{Relevance to developing countries}

Our proposed strategy is modelled in part on the Australian WONS approach (Thorpe \& Lynch 2000), with the use of geographic differentiation to formulate different objectives and approaches for different parts of the species' range, as proposed by Grice et al. (2011). Reviews of the WONS programme in Australia have revealed several positive consequences and highlighted areas in which the approach could be improved (Beatentrack 2008; Raphael et al. 2010; Reid et al. 2009). There is general agreement that the strategy of targeting WONS had led to marked improvements in awareness, as well as in collaborative governance and the ecological understanding of the target weeds. However, it was found that performance indicators in individual species strategies had been developed at too broad a level, and that they generally lacked quantitative measures and timelines against which progress could be assessed (Beatentrack 2008). Stakeholder surveys have also pointed to a widely perceived need for improved monitoring and evaluation (Raphael et al. 2010). The effectiveness of the proposals for geographical differentiation of management goals (Grice et al. 2011) have not been assessed, although they were useful in the formulation of the strategy described here. Thus, even in developed countries like Australia, it has proved difficult to quantify the effectiveness of management interventions.

There are clearly several factors that would make the implementation of control strategies for priority species more 
TABLE 4: Possible outcomes of selected high-level indicators for assessing progress with the implementation of a national strategy to manage Parthenium hysterophorus in South Africa and proposed appropriate management responses.

\begin{tabular}{ll}
\hline Indicator & Possible outcomes \\
\hline $\begin{array}{l}\text { Number of new } \\
\text { infestations detected } \\
\text { in previously } \\
\text { unoccupied areas }\end{array}$ & No new infestations detected \\
& $\begin{array}{l}\text { Some new infestations detected } \\
\text { Large numbers of new infestations detected }\end{array}$ \\
$\begin{array}{l}\text { Number of reported } \\
\text { sightings and time } \\
\text { taken to carry out } \\
\text { assessments }\end{array}$ & $\begin{array}{l}\text { Relatively few new sightings and/or assessments are carried } \\
\text { out rapidly (within less than three months) }\end{array}$ \\
& $\begin{array}{l}\text { Moderate numbers of new sightings and/or some assessments } \\
\text { taking longer than three months to complete } \\
\text { Large numbers of new sightings and/or many assessments not } \\
\text { carried out within six months }\end{array}$
\end{tabular}

Number of successful Populations are successfully removed from target area local eradication campaigns Populations are removed from target area but sites become re-invaded within two years

Local eradication campaigns are unable to remove populations from target area

Number of containment campaigns with adequate management plans

All municipalities in containment and asset protection zones have adequate management plans

More than half of the municipalities in containment and asset protection zones have adequate management plans

Less than half of municipalities in containment and asset protection zones have adequate management plans

Effectiveness of biological control Complete control is achieved. No other control measures are needed to reduce the weed to acceptable levels

Substantial control is achieved. Other methods are needed to reduce the weed to acceptable levels but less effort is required Negligible control is achieved. Despite damage, control of the weed remains entirely reliant on the implementation of other control measures

Area covered by populations of Area covered decreases over time

Area covered remains constant or increases slowly
Appropriate responses

Steps taken to reduce the risks of movement appear to be adequate, continue with these interventions

Steps taken to reduce the risks of movement may require strengthening

Steps taken to reduce the risks of movement appear to be inadequate. They either need to be substantially strengthened, and if this is not feasible, resources should be allocated to alternative interventions. Treat all new infestations as containment zones

Steps taken to carry out rapid assessments appear to be adequate, continue with these interventions

Steps need to be taken to expedite assessments

Steps taken to carry out rapid assessments appear to be inadequate, and isolated populations will in most cases grow to a size where local eradication is no longer an option. Treat all new infestations as containment zones

Continue with local eradication campaigns as and where needed

Re-assign the area to a containment zone

Local eradication of this species not feasible. Discontinue attempts and treat all new sites as containment zones

No response required

Steps are required to assist those municipalities that are not able to produce adequate management plans

Steps are required to establish the reasons for inadequate planning and to address those

Chemical control can be limited to the protection of important assets

Chemical control should be integrated at a landscape scale with biological control to ensure optimal outcomes

Further progress would be entirely reliant on chemical control or suppression using other plants (Khan et al. 2014; Shabbir et al. 2013) unless further, more effective agents can be found

Steps taken appear to be effective and should be continued

Steps taken may be contributing to slowing the rate of invasion and should be continued. Research is needed to assess the contribution of management to this outcome (e.g. Ferraro \& Hanauer 2014) and to inform ways of improving management effectiveness

Current management interventions are ineffective, and future interventions should focus on asset protection.

Note: The biological control outcomes are after Klein (2011).

difficult to implement in developing countries, as such countries lack the resources and expertise that are available in Australia. A simple comparison between Australia and South Africa indicates several such factors. These include levels of affluence and education that will affect the relative difficulty of implementing widespread control programmes. For example, the overall and per capita GDP in 2015 was $\sim$ US $\$ 1500$ billion or $\sim$ US $\$ 45000$ per person in Australia compared with $\sim$ US\$366 billion or US\$12 000 per person in South Africa (estimates vary according to a range of assumptions and methodologies; e.g. http://statisticstimes. com/economy/countries-by-projected-gdp-capita.php; https://en.wikipedia.org/wiki/List_of_IMF_ranked_ countries_by_past_and_projected_GDP_\%28PPP\%29). Overall education levels (based on the UN education index, see http://hdr.undp.org/en/content/education-index) are higher (0.927) in Australia than in South Africa (0.695), and perhaps more importantly, the disparity between the rich and the poor is noticeably more marked in South Africa than in Australia (Gini coefficients of 0.631 and 0.305 , respectively). It is thus more likely that control programmes will succeed in Australia as the general population will be able to better afford control efforts and will be better placed to access and use information. Additional factors that will promote more rapid movement of $P$. hysterophorus across the landscape include the relatively high human population densities in South Africa when compared with Australia (44 vs. 3 people $/ \mathrm{km}^{2}$ ) and the absence of international borders in Australia. Most importantly, the possession of livestock is of enormous cultural importance in communal rangelands in South Africa, leading to overstocking, providing a significant challenge to the management of P. hysterophorus.

South Africa, on the contrary, is relatively well off when compared with other developing nations. For example, P. hysterophorus is spreading through Swaziland, Mozambique and Zimbabwe, which have even less resources for dealing with the problem (per capita GDPs of $\sim$ US\$6700, 1100, and 1800 per person for 2015, respectively). While it is in the interest of relatively richer countries to assist their neighbours with the control of alien plants that will pose high risks across international borders, the reality remains that the effective implementation of co-ordinated strategic control programmes will be difficult. In the case of P. hysterophorus, effective biological control offers some hope of reducing the problem to manageable proportions, as it has been done in Australia. It is ironic that many developing nations are opposed to the use of biological control, as in many cases it offers a safe and effective way of addressing problems of invasion (Sheppard et al. 2003; van Wilgen, Moran \& Hoffmann 2013). We would therefore recommend, in this and many other cases, that biological control be considered as a vital and indispensable component of any alien plant control strategy in developing countries. 


\section{Acknowledgements}

Financial support for the strategy was provided by the Department of Environmental Affairs-Natural Resource Management Programme. We thank the participants of the workshops, and others, for inputs into the development of this strategy, particularly Philip Blackmore, Michael Braack, Ian Macdonald, Rachel McFadyen, Ian Rushworth, John Wilson and Helmuth Zimmermann. BvW thanks the DST-NRF Centre of Excellence for Invasion Biology and the South African National Biodiversity Institute (SANBI) for funding his involvement. LS, JG and AM thank the Agricultural Research Council of South Africa for facilitating their involvement. HK and IN thank SANBI for the administration behind the strategy.

\section{Competing interests}

The authors declare that they have no financial or personal relationships which may have inappropriately influenced them in writing this article.

\section{Authors' contributions}

C.B. led the development of the strategy; L.S. and A.M. made inputs regarding biological control. All of the authors participated in workshops and reviewed various drafts of the strategy. B.v.W. wrote the entire paper for publication.

\section{References}

Adkins, S. \& Shabbir, A., 2014, 'Biology, ecology and management of the invasive parthenium weed (Parthenium hysterophorus L.)', Pest Management Science 70 parthenium weed (Parthenium hysterophorus 1 .

Beatentrack, 2008, Review of the management of weeds of national significance, Report to the Department of Agriculture, Fisheries and Forestry, Canberra.

Blossey, B., 1999, 'Before, during and after: The need for long-term monitoring in invasive plant species management', Biological Invasions 1, 301-311. http:// dx.doi.org/10.1023/A:1010084724526

Brunel, S., Panetta, D., Fried, G., et al., 2014, 'Preventing a new invasive alien plan from entering and spreading in the Euro-Mediterranean region: The case study of Parthenium hysterophorus', EPPO Bulletin 44, 479-489. http://dx.doi. org/10.1111/epp.12169

Denslow, J.S. \& D'Antonio, C.M., 2005, 'After biocontrol: Assessing indirect effects of insect releases', Biological Control 35, 307-318. http://dx.doi.org/10.1016/j. biocontrol.2005.02.008

Dhileepan, K. \& McFadyen, R.C., 2012, 'Parthenium hysterophorus L. - parthenium', in J. Cullen, M. Julien \& R. McFadyen (eds.), Biological control of weeds in Australia, pp. 448-462, CSIRO Publishing, Australia.

Ferraro, P.J. \& Hanauer, M., 2014, 'Advances in measuring the environmental and social impacts of environmental programs', Annual Review of Environment and Resources 39, 397-417. http://dx.doi.org/10.1146/annurev-environ-101813-013230

Grice, A.C., Clarkson, J.R. \& Calvert, M., 2011, 'Geographic differentiation of management objectives for invasive species: A case study of Hymenachne amplexicaulis in Australia', Environmental Science and Policy 14, 986-997. http:// amplexicaulis in Australia', Environmental
dx.doi.org/10.1016/j.envsci.2011.07.006

Henderson, L., 2007, 'Invasive, naturalized and casual alien plants in southern Africa: A summary based on the Southern African Plant Invaders Atlas (SAPIA)', Bothalia 37, 215-248. http://dx.doi.org/10.4102/abc.v37i2.322

Hilliard, O.M., 1977, Compositae in Natal, University of Natal Press, Pietermaritzburg, South Africa.

Kettenring, K.M. \& Adams, C.R., 2011, 'Lessons learned from invasive plant control experiments: A systematic review and meta-analysis', Journal of Applied Ecology 48, 970-979. http://dx.doi.org/10.1111/j.1365-2664.2011.01979.x

Khan, N., Shabbir, A., George, D., Hassan, G. \& Adkins, S.W., 2014, 'Suppressive fodder plants as part of an integrated management program for Parthenium hysterophorus L.', Field Crops Research 156, 172-179. http://dx.doi.org/10.1016/j.fcr.2013.11.003
Klein, H., 2011, 'A catalogue of the insects, mites and pathogens that have been used or rejected, or are under consideration, for the biological control of invasive alien plants in South Africa', African Entomology 19, 515-549. http://dx.doi.org/ plants in South Afric
$10.4001 / 003.019 .0214$

Macdonald, I.A.W., 2014, 'What's in a name? The conscious decision to choose 'famine weed' as the English common name for the invasive alien plant Parthenium hysterophorus in South Africa', International Parthenium News 10, 2-4.

McConnachie, A.J., Strathie, L.W., Mersie, W., et al., 2011, 'Current and potential geographical distribution of the invasive plant Parthenium hysterophorus (Asteraceae) in eastern and southern Africa, Weed Research 51, 71-84. http:// dx.doi.org/10.1111/j.1365-3180.2010.00820.x

Navie, S.C., McFadyen, R.E., Panetta, F.D. \& Adkins, S.W., 1998, 'Behaviour of buried and surface sown seeds of Parthenium hysterophorus', Weed Research 38 , 335-341. http://dx.doi.org/10.1046/j.1365-3180.1998.00104.x

Panetta, F.D. \& Cacho, O.J., 2014, 'Designing weed containment strategies: An approach based on feasibilities of eradication and containment', Diversity and Distributions 20, 555-566. http://dx.doi.org/10.1111/ddi.12170

Patel, S., 2011, 'Harmful and beneficial aspects of Parthenium hysterophorus: An update', Biotech 1, 1-9. http://dx.doi.org/10.1007/s13205-011-0007-7

Pimentel, D., 2011, Biological invasions: Economic and environmental costs of alien plant, animal and microbe species, CRC Press, Boca Raton.

Raphael, B., Baker, J., Tennant, P., Sparkes, J. \& McCowen, S., 2010, Stakeholder perceptions of the weeds of national significance program and progress against individual species plans, Bureau of Rural Sciences, Canberra.

Reid, A.M., Morin, L., Downey, P.O., French, K. \& Virtue, J.G., 2009, 'Does invasive plant management aid the restoration of natural ecosystems?', Biological Conservation 142, 2342-2349. http://dx.doi.org/10.1016/j.biocon.2009.05.011

Shabbir, A., Dhileepan, K., O’Donnell, C. \& Adkins, S.W., 2013, 'Complementing biological control with plant suppression: Implications for improved management of parthenium weed (Parthenium hysterophorus L.)', Biological Control 64, 270275. http://dx.doi.org/10.1016/j.biocontrol.2012.11.014

Sheppard, A.W., Hill, R., DeClerck-Floate, R.A., et al., 2003, 'A global review of risk benefit-cost analysis for the introduction of classical biological control agents against weeds: A crisis in the making?', Biocontrol News and Information 24 $91 \mathrm{~N}-108 \mathrm{~N}$

Strathie, L.W., McConnachie, A.J. \& Retief, E., 2011, 'Initiation of biological control against Parthenium hysterophorus L. (Asteraceae) in South Africa', African Entomology 19, 378-392. http://dx.doi.org/10.4001/003.019.0224

Terblanche, C., 2014a, 'National strategy for the management of famine weed (Parthenium hysterophorus) in South Africa 2015-2018', Department of Environmental Affairs, Pretoria.

Terblanche, C., 2014b, National implementation plan for the management of famine weed (Parthenium hysterophorus) in South Africa 2015-2016, Department of Environmental Affairs, Pretoria.

Thorp, J.R. \& Lynch, R., 2000, The determination of weeds of National Significance, National Weeds Strategy Executive Council, Launceston.

Towers, G.H.N. \& Mitchell, J.C., 1983, 'The current status of the weed Parthenium hysterophorus L. as a cause of allergic contact dermatitis', Contact Dermatitis 9, 465-469. http://dx.doi.org/10.1111/j.1600-0536.1983.tb04465.x

Van Wilgen, B.W., Le Maitre, D.C. \& Cowling, R.M., 1998, 'Ecosystem services, efficiency, sustainability and equity: South Africa's Working for Water programme', Trends in Ecology and Evolution 13, 378. http://dx.doi.org/10.1016/S01695347(98)01434-7

Van Wilgen, B.W., Dyer, C., Hoffmann, J.H., Ivey, P., Le Maitre, D.C., Richardson, D.M., Rouget, M., Wannenburgh, A. \& Wilson, J.R.U., 2011, 'National-scale strategic approaches for managing introduced plants: Insights from Australian acacias in South Africa', Diversity and Distributions 17, 1060-1075. http://dx.doi. South Africa', Diversity and Distributio
org/10.1111/j.1472-4642.2011.00785.x

Van Wilgen, B.W., Forsyth, G.G., Le Maitre, D.C., et al., 2012, 'An assessment of the effectiveness of a large, national-scale invasive alien plant control strategy in South Africa', Biological Conservation 148, 28-38. http://dx.doi.org/10.1016/j. biocon.2011.12.035

Van Wilgen, B.W., Moran, V.C. \& Hoffmann, J.H., 2013, 'Some perspectives on the risks and benefits of biological control of invasive alien plants in the management of natural ecosystems', Environmental Management 52, 531-540. http://dx.doi. natural ecosystems', Environmental
org/10.1007/s00267-013-0099-4

Van Wilgen, B.W. \& Wannenburgh, A., 2016, 'Co-facilitating invasive species control, water conservation and poverty relief: Achievements and challenges in South
Africa's Working for Water programme', Current Opinion in Environmental Sustainability 19, 7-17. http://dx.doi.org/10.1016/j.cosust.2015.08.012

Wise, R.M., van Wilgen, B.W., Hill, M.P., et al., 2007, The economic impact and appropriate management of selected invasive alien species on the African continent, Report number: CSIR/NRE/RBSD/ER/2007/0044/C, Council for Scientific and Industrial Research, Stellenbosch.

Wood, J.M., 1897, Report on Natal Botanic Gardens for the year 1896, Durban Botanic Society, Durban. 